\title{
コーテッドエ具” スローアウェイチップ
}

\section{狩野勝吉** 長田 晃*** 吉村寞範 ${ }^{* * *}$}

CVD Coated Carbide Tools - Throw-away Tip /

Katsuyoshi KARINO, AKira OSADA and Hironori YOSHIMURA

Key words: CVD, coating technology, coated tool, throw-away tip, tool wear,

high speed cutting

1. は じめに

わが国の機械加工は，円高や高兵金，雇用確保，設備費 増大といった諸問題を抱光，厳しい国際的・社会的・技術 的環境の中に立たされている，加工現場では，思い切った 高速・高能率加工によって，「倍速加工」や「生産コスト半 減」を実現しょうとする動きが活発である。

切削加工の技術革新を獲得していく過程で, キーテク， ロジーとなるのは切削工具の切れ刃である. 生産活動を取 り巻く厳しい現状を打開するためにも，切削性能の優れた 新しい工具材種の開発が待ち望まれている.

コーテッド超硬合金は，切削加工の高能率化 と低コスト化にとって極めて重要な切削工具の 一つである、特に, CVD コーティング技術の 分野では，新しい技術思想に基ついて開発され た工具材種が，市場でのシェア抎大に寄与し， この不況時にあっても,コーテッド超硬合金の 生産比率は鈍化していない。

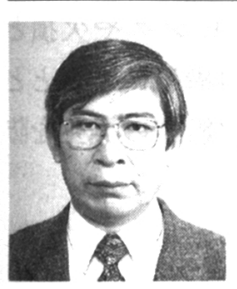

* 原稿受付 平成 7 年 4 月 27 日 * 正会員三葼マテリアル(株) 筑波製作所（荻城県結城郡石下 町古間木 1511)

*** 三菱マテリアル(株)筑波製作所 狩野勝吉

1960 年三菱マテリアル(株)入 社, 1968 年中央大学法学部卒. 現在筑波製作所工具グルーブ課 長代理。著書：「難削材の切削加工技術」「「データでみる切 削加工の最先端技術」

長田 晃

1985 年東京大学丁学部金属丁学科卒。同年, 二菱マテリ了儿 (株)入社. 現在, 材料グループ主任技師

吉村寛範

1971 年横浜国立大学金属厂学科修了。同年, 三菱マテリアル (株)入社. 現在, 筑波製作所技術開発センター長
2. コーテッド超硬合金とコーティング技術

\section{1 コーテッド超硬合金の生産比率}

図 1 は, 過去 15 年間のスローアウェイチップの 1 か月 当たりの生産数量並びに生産比率の推移を工具材料別に比 較したものである。

生産数量は, 景気の変動によって増減はあるが, 生産比 率でみると，コーテッド超硬合金は，一貫して増加傾向を 示し，1994 年には，全体の $46 \%$ にまで達している. 反対 に，一般超硬合金の生産比率は，年ごとに減少し，1993
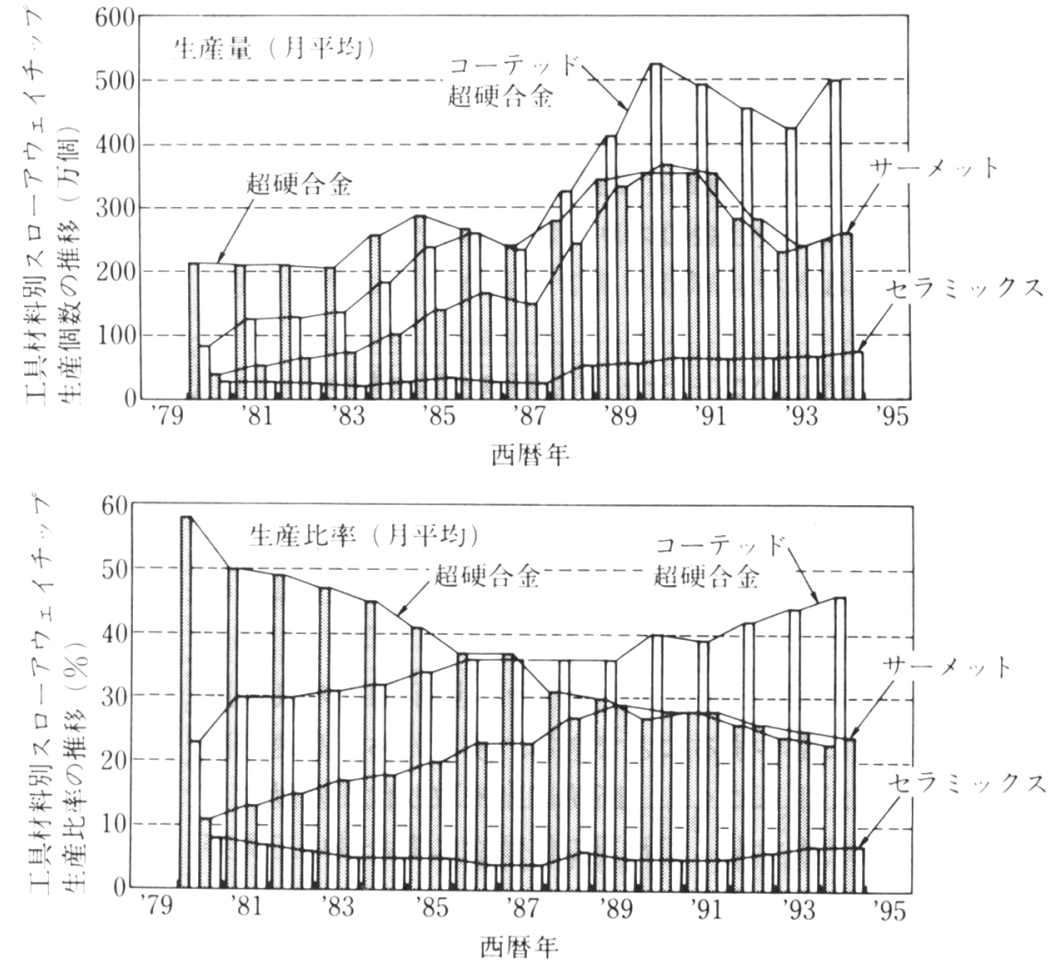

図 1 スローアウェイチップの生産量と生産比率 
表 1 コーティング技術の変遷

\begin{tabular}{|c|c|c|}
\hline & コーティング層 & $\begin{array}{l}\text { 三菱マテリアル } \\
\text { の該当材種 }\end{array}$ \\
\hline \multirow{2}{*}{ 第一世代 } & 単 層 & B 221 \\
\hline & (TiC, TiN など) & B 331 \\
\hline \multirow{2}{*}{ 第二世代 } & 複 層 & U 77 \\
\hline & $\left(\mathrm{TiC}-\mathrm{Al}_{2} \mathrm{O}_{3}\right.$ など) & U 88 \\
\hline \multirow{2}{*}{ 第三世代 } & 多重層 & U 610 \\
\hline & 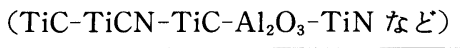 & $\mathrm{U} 625$ \\
\hline \multirow{2}{*}{ 第四世代 } & 強じん厚膜 & UC 6010 \\
\hline & $\left(\mathrm{TiCN}-\mathrm{Al}_{2} \mathrm{O}_{3}-\mathrm{TiN}\right.$ など) & UC 6025 \\
\hline
\end{tabular}

年には全体の $25 \%$ 割り込んだ。そして，1994 年には 23\%にをで落ち込んでいる。コーテッド超硬合金と一般

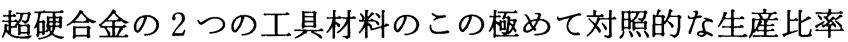
の推移は, 加工現場が, 切削加工の高速化, 高能率化, 低 コスト化の実現に果敢に取り組んできた経緯を如実に示す ものと言ってよい.

サーメット材種も，1989 91 年をピークに生産比率が 減少に転じたが，これも高能率・低コスト切削を目指した 自動加工では, 切削工具としての信頼性の面で, コーテッ ド超硬合金の特性が優れているため, サーメット材種に対 する市場での評価がコーテッド超硬合金に及ばなかったた めと考兄られる。

\section{2 コーティング技術の変僄}

コーテッド超硬合金が，他の工具材料に比べて，圧倒的 に高い生産比率を示すに至った理由として, 実用化以来, 25 年余にわたって絶えず切削性能の改良開発が行われて きたことも見逃せない，

表 1 は,これまでの数次にわたる CVD コーティング技 術の改良経緯について，これを第一世代一第四世代に区分 して示したものである.ここでは，三菱マテリアルの $\mathrm{CVD}$ コーティング技術とその技術を応用して商品化され た新コーテッド超硬合金のスローアウェイチップ UC 6010 について述べる.

\section{3. 新しいコーテッド材種の切削特性}

\section{1 新しい切削工具に要求される特性}

切削加工に扮いて，高品質の製品を高能率・低コストで 生産し，市場に供給しょうとすると，新しい切削工具への

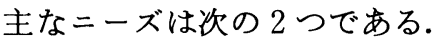

1 つは, 耐摩耗性と耐欠損性に優れ, 切削加工の高精度 化と高能率化に寄与することである．すなわち，高速切削 でも工具摩耗が生じにくく，断続切削や取り代が変動する 不安定な黒皮切削でも，切れ刃の信頼性に富む長い工具寿 命が得られることである.

2 つは，汎用性が高く加エコストの低減に寄与すること である. 切削速度, 切込み, 送りなどの加工条件が幅広く

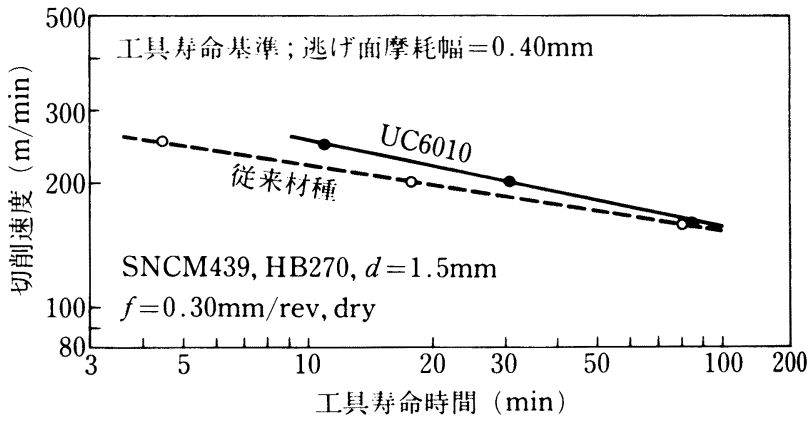

図 2 コーテッド材種 UC 6010 と従来材種の $V$ - $T$ 線図

変化しても切削性能が安定すること，炭素鋼，合金鋼，ね ずみ鋳鉄，ダクタイル鋳鉄といった多種類の被削材に適用 しても，従来のそれぞれの専用材種よりも優れた工具寿命 と信頼性が得られる切削性能をるつことである.

コーテッド材種 UC 6010 も，こうした幅広い用途を意 識して開発されたものである.

\section{2 耐摩耗性と耐欠損性の向上}

高速・高能率切削を実現するためには，耐摩耗性に優れ た工具材種が求められる.

図 2 は，合金鋼 SNCM 439 を切削して，切削速度と工 具寿命の関係を実験した $V-T$ 線図である. UC 6010 は, 従来材種に比べると, 高速切削領域ほど長い工具寿命が得 られている，後述するように，耐摩耗性の向上を図るため コーティング層は, 従来材種の 1.5 倍程度まで厚膜とし, かつ、コーティング物質の脱落や破壊が生じないように, 特殊な瀻維状組織に改良して強じん化したのが特徵で，高 速切削でも工具摩耗が生じにくく, 安定した工具寿命が得 られる材料設計になっている。

一方，加工能率の向上や加工コストの低减には，切削加 工の自動化や無人化が不可欠である. 切削工具は, 耐摩耗 性だけでなく，耐欠損性にも優れることが要求される.

図 3 は，断続切削による耐欠損性の実験結果を連続切削 による耐摩耗性の実験結果と合わせて整理した切削データ である. UC 6010 は高速切削用の各種の従来材種に比べて も，切れ刃欠損が生じにくい切削特性をもつ.

耐欠損性の向上については，コーティング層直下の母材 表面に強じん層を形成し，切れ刃のチッピングや欠損と いったぜい性損傷が起こらないように傾斜構造にするとと もに，コーティング工程中に起こるぜい化組織の発生を防 止している。

\section{3 沉用特性の向上}

これまで，コーテッド材種の開発は，鋼切削用，鋳鉄切 削用などと，被削材別に専用化，細分化する傾向が強かっ た. そのため, 工具材種の数は増加し続け，切削工具を使 用する立場からみると，適正な専用材種を選択することが 煩雑で困難なものとなり，工具材種の集約化の要請が高 

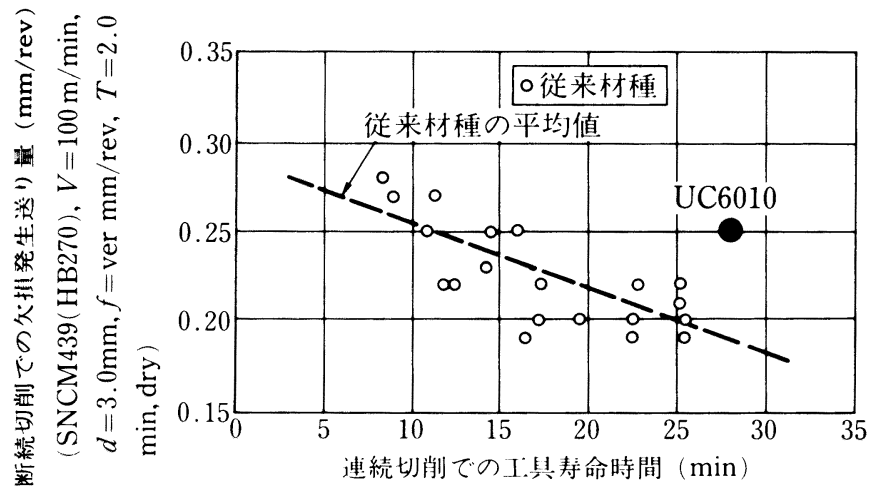

(SNCM439(HB270), $V=200 / \mathrm{min}, d=1.5 \mathrm{~mm}$, $f=0.30 \mathrm{~mm} / \mathrm{rev}$, dry $)$

(工具陦命基潐; 逃げ面摩耗幅 $=0.35 \mathrm{~mm}$ )

図 3 断続切削での耐欠損性と連続切削での工具寿命長さ

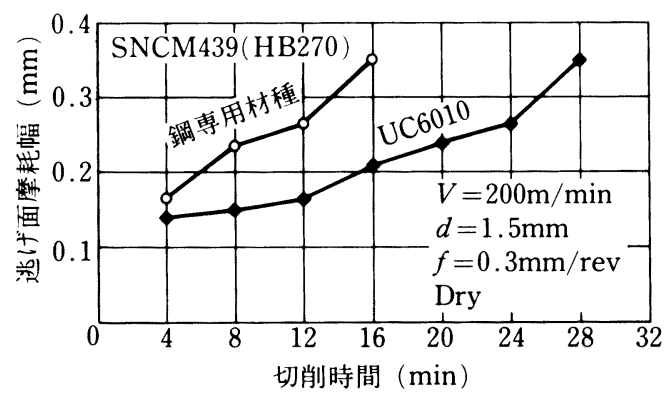

SNCM439 の切削

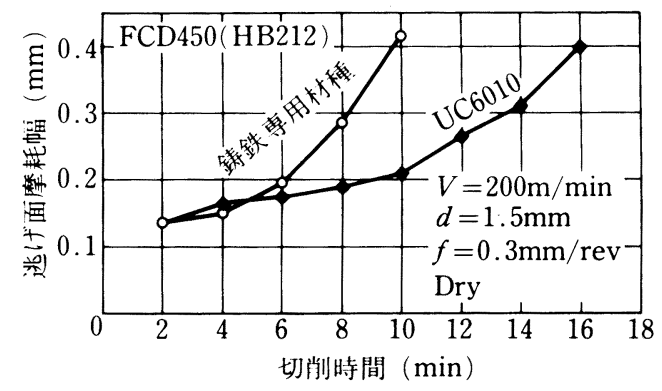

FCD450 の切削

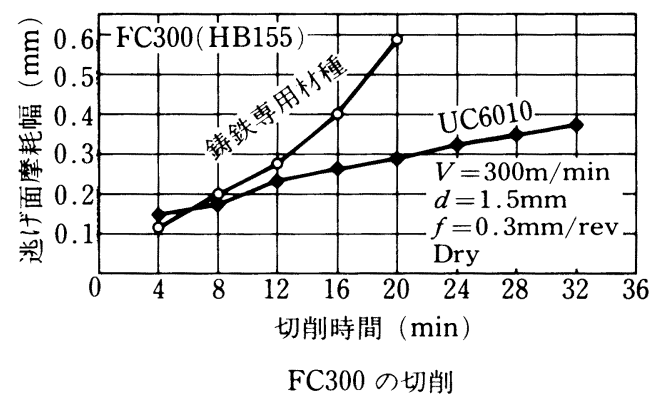

図 4 UC 6010 の被削材別工具摩耗進行

まっている.

図 4 は合金鋼 SNCM 439, ダクタイル鋳鉄 FCD 450, ねずみ鋳鉄 FC 300 を切削して，従来のそれぞれの専用材 種と工具摩耗進行を比較したものである. UC 6010 は, 従 来の専用材種と比較して, 汎用性に優れた切削性能を示 す. 材質の異なる部品の混流ラインへ適用しても，また， 購買部や工具管理部で思い切った工具材種の集約化を図っ
ても, 切削加工の高速化, 長寿命化, 低コスト化が十分可 能な切削特性を示している.

図 5 には，合金鋼 SCM 440 とねずみ鋳鉄 FC 300 を切 削し，逃げ面摩耗幅 $0.40 \mathrm{~mm}$ を基準とするときのそれぞ れの工具寿命時間を示す. 被削材質に対する新しいコー テッド材種の汎用性は極めて高いことが分かる.

\section{4. 新しいコーテッド材種の材料特性}

従来のコーテッド超硬合金では，耐摩耗性を向上させる ためにコーティング層を厚膜化すると, 耐摩耗性は向上す るが，一方で強度の低下による切れ刃のチッピングや欠 損, コーティング層そのものの破壊等の問題があった.

UC 6010 では，これまでとは異なる新しいCVD ュー ティング技術の開発により，主コーティング層である $\mathrm{TiCN}$ の結晶形態を制御することでこの問題を解決した.

\section{1 工具摩耗を抑制するコーティング技術}

図 6 は, コーティング層の破断面組織を走査型電子顕微 鏡により観察したものである. 従来材種のコーティング層 の結晶形態は粒状を呈しているのに対し, UC 6010 の $\mathrm{TiCN}$ 層は幅 $1 \mu \mathrm{m}$, 長さ $7 \sim 8 \mu \mathrm{m}$ 程度の繊維状の結晶が 超硬合金母材の表面に垂直な方向に成長する形で形成され ている.

このような特殊な繊維状組織に制御され強じん化された $\mathrm{TiCN}$ 層により, 従来の粒状組織からなるコーテッド超硬 合金と比べ，コーティング層の全体の厚さを 1.5 倍に厚膜 化することが可能となった． また， TiCN は TiC と TiN のそれぞれの特徵である耐逃げ面摩耗性と耐すくい面摩耗 性をバランスよく兼ね備えているため, 従来材種で行われ ていた多層化による各特性の複合の必要もなくなった.

このような優れた特性をもつ $\mathrm{TiCN}$ 層と耐摩耗性の高 い $\mathrm{Al}_{2} \mathrm{O}_{3}$ 層, 黄金色の外観をるたせる極薄の $\mathrm{TiN}$ 層とか ら構成された UC 6010 は, 前述のよらな広範囲な被削材, 切削条件に打いて極めて高い耐摩耗性を示す工具材種と

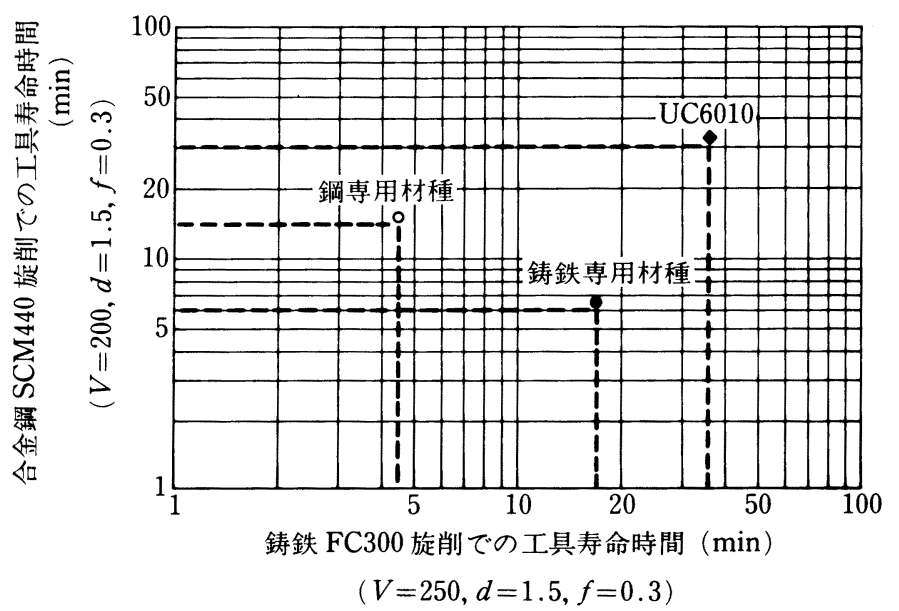

図 5 UC 6010 の被削材汎用性 （工具寿命基準；逃げ面摩耗幅 $0.40 \mathrm{~mm}$ ) 


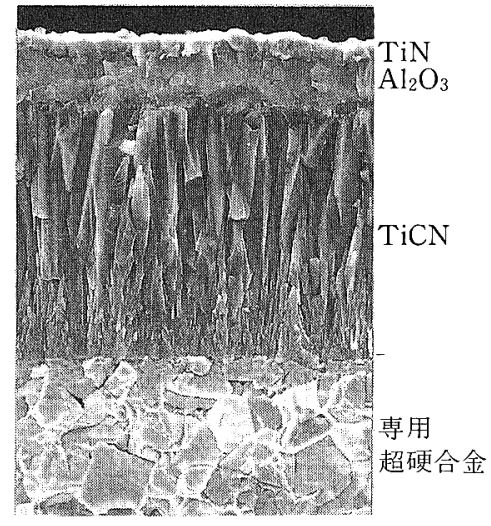

(a) 新枌種 (UC6010)

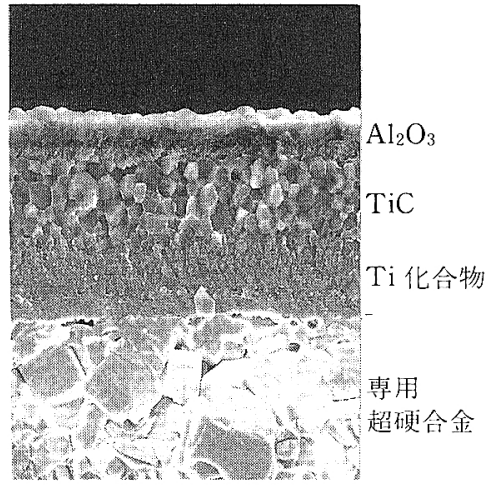

(b) 従来枋種

図 6 コーティング層破断面の走查型電子顕微鏡組織

なっている.

\section{2 切れ刃欠損を防止するコーティンク} 技術

この新しく開発された繊維状組織を呈する $\mathrm{TiCN}$ 層のもら一つの大きな特徵として，超 硬合金の強度を低下させるク相（ぜい化 相：Co $\mathrm{C}_{y} \mathrm{C}$ ）の生成を完全に抑觉るという 点があげられる.

従来の CVD コーティング法では, $\mathrm{TiC}$ 等 をコーティングする場合，コーティング時に 次式のような反応によって超硬合金の母材表 面に $\eta$ 相が生成される。

$$
2 \mathrm{Ti}+3 \mathrm{WC}+3 \mathrm{Co} \rightarrow 2 \mathrm{TiC}+\mathrm{Co}_{3} \mathrm{~W}_{3} \mathrm{C}
$$$$
5 \mathrm{Ti}+6 \mathrm{WC}+6 \mathrm{Co} \rightarrow 5 \mathrm{TiC}+\mathrm{Co}_{6} \mathrm{~W}_{6} \mathrm{C}
$$

図 7 に示されるよらに，＼cjkstart相が生成すると超硬合金の強 度（抗折力）は大きく低下する。このため，母材表面に生 成した $\eta$ 相は，コーテッド超硬合金の耐欠損性を著しく 低下させると共にコーティング層の剝離の原因ともなる。

図 8 は, コーティング層和よび母材表面部の組織を光学 顕微鏡により観察したものである。従来材種ではコーティ ング層直下の母材表面に多量の $\eta$ 相が生成しているのに 対し，UC 6010 には全く生成していない，更に，UC 6010 の超硬合金母材は，その表面部が内部よりじん性の高い傾 斜構造を呈している。この特殊超硬合金母材では，図 9 の ように，強じんな表面部で切削中にコーティング層に発生 したクラックの進行が阻止されるため，コーテッド超硬合 金の耐欠損性の向上が図られた。

この 2 つの技術の相乗効果により，断続切削等のように 高い切れ刃強度が要求される切削に打いても, 信頼性の高 い安定した工具寿命が得られるようになった。

\section{5. 材料特性と工具損傷形態との関係}

新材種 UC 6010 と従来材種 との材料特性の差が工具損 傷形態にどのような違いとして現れるかを確認するため,

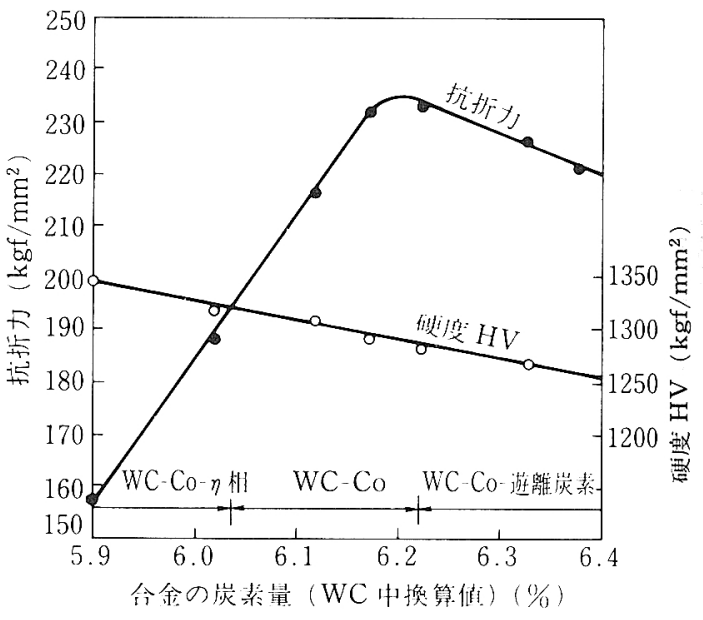

図 7 WC-10\% 超硬合金の曲げ強度（抗折力）に及活す 炭素量の影響

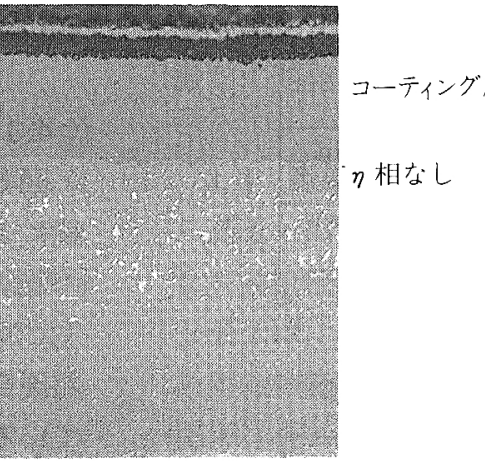

a) 新材種 (UC6010)

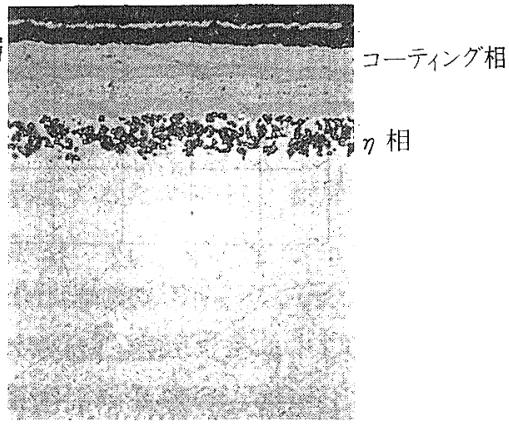

(b) 従来材種

图 8 コーティング層ラップ面の光学顕微鏡組織

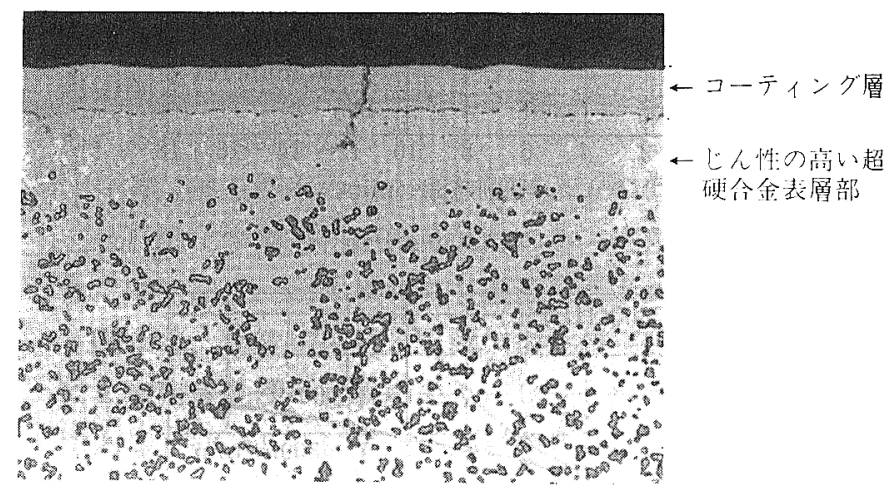

図 9 コーティング層から入ったクラックが，じん性の高い表面部 で止まったことを示す写真

走查型電子顕微鏡により摩耗面の詳細な観察を行った。

図 10〜12 は，図 4 に示した合金鋼 SNCM 439 の切削を 行ったときの切れ刃の損傷を詳細に観察したものである.

図 10 は，工具摩耗部全体の切れ刃状態，図 11 は，その 一部を㹡大して示したものである．従来材種は摩耗面全体 に被削材が溶着しているのに対し，UC 6010 の摩耗面には 溶着物が少なくコーティング層の耐溶着性が向上している ことが確認できる。

図 12 は，摩耗面の溶着物を酸により除去し，図 10 の切 れ刃部をさらに高倍率で観察したものである。両工具とも 


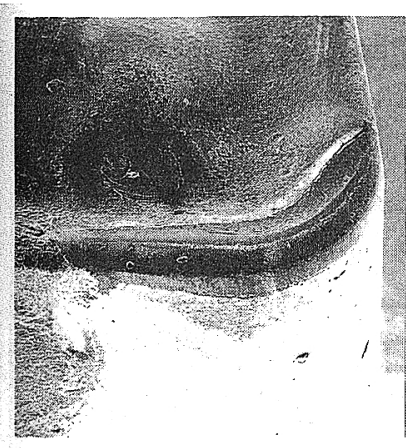

(a) UC6010 切削時間 16 分

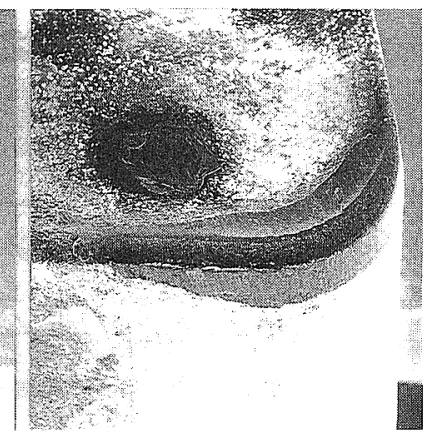

(b) 従来材柇 切削時間 16 分

被削材：SNCM 439 (HB 270), 工具：PCLNL 2525 M 12, CNMG $432 \mathrm{MA}$, 切削条件： $V=200 \mathrm{~m} / \mathrm{min}, d=1.5 \mathrm{~mm}$, $f=0.3 \mathrm{~mm} / \mathrm{rev}$, 乾式切削

図 10 走査型電子顕微鏡による工具損傷観察-1(切れ刃全体)

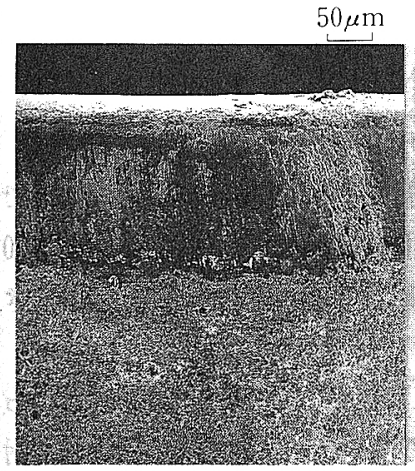

(a) UC6010 奵削時間 16 分

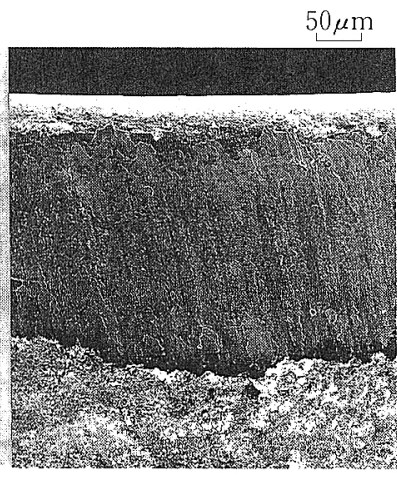

(b) 従来材種 断削時間 16 分
被削材：SNCM 439 (HB 270), 工具：PCLNL 2525 M 12, CNMG $432 \mathrm{MA}$, 切削条件: $V=200 \mathrm{~m} / \mathrm{min}, d=1.5 \mathrm{~mm}$, $f=0.3 \mathrm{~mm} / \mathrm{rev}$, 乾式切削

图 11 走査型電子顕微鏡による工具損傷観察-2（逃沪面摩耗部分）

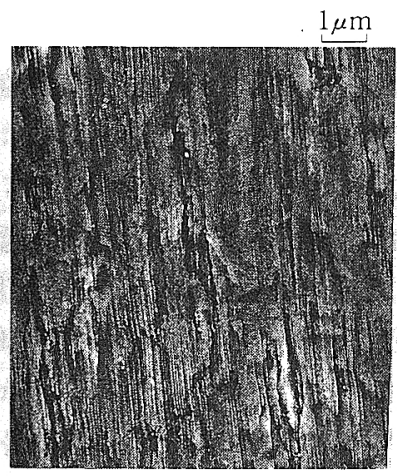

(a) UC6010 切削時間 16 分

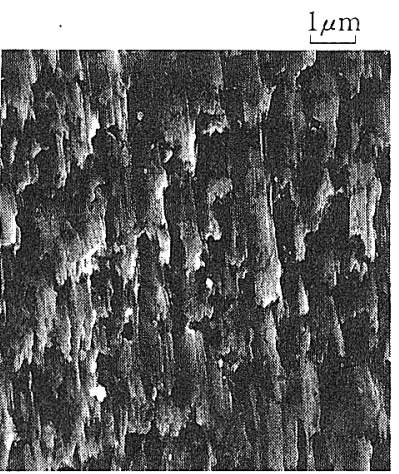

(b) 従来材種 切削時間 16 分
被削材：SNCM 439 (HB 270), 工具：PCLNL 2525 M 12, CNMG $432 \mathrm{MA}$, 切削条件: $V=200 \mathrm{~m} / \mathrm{min}, d=1.5 \mathrm{~mm}$, $f=0.3 \mathrm{~mm} / \mathrm{rev}$, 乾式切削

図 12 走査型電子顕微鏡による工具損傷観察-3（溶着物除去 後の逃げ面摩耗面の㹡大)

に逃げ面摩耗部にコーティング層が残って扣り、コーティ ング層の摩耗状態を比較できる。従来材種の摩耗面は凹凸 が激しく, 0.1 0.5 $\mu \mathrm{m}$ 程度の幅の摩耗痕が生じている.

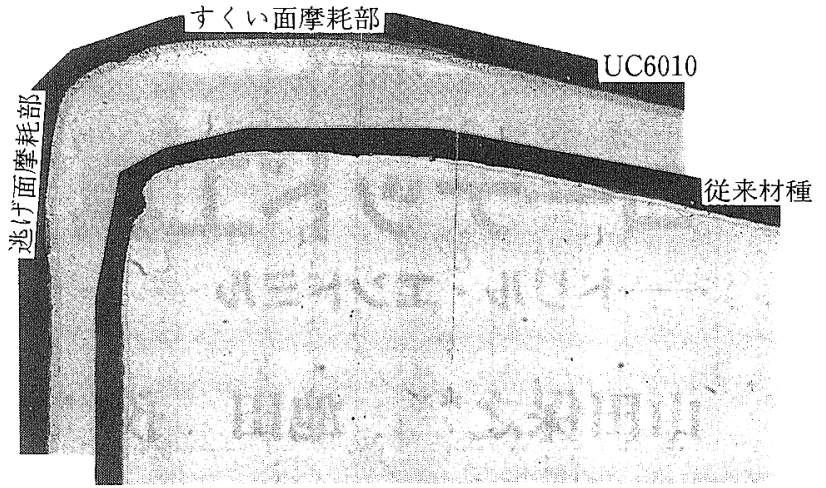

FC 300, HB $155, V=300 \mathrm{~m} / \mathrm{min}, \quad f=0.3 \mathrm{~mm} / \mathrm{rev}, \quad T=8$ min, dry

図 13 直角断面を光学影微鏡でみたコーティング層の消失状態

凹凸や摩耗痕の大きさは図 6 で示した従来材種のコーティ ング層の結晶粒の大きさとよく一致している。このことか ら, 従来材種の摩耗面ではコーティング層の結晶粒の脱落 や破壊による摩耗粉が多く生じ，この硬質の摩耗粉が被削 材とともにコーティング層表面を擦過していくことにより 摩耗進行が加速されると考学られる。これに対し， UC 6010 の摩耗面には山凸が少なく摩耗痕は $0.1 \mu \mathrm{m}$ 以下 のものが多い, したがって，この場合は，摩耗面でュー ティング層の結晶粒の脱落や破壊が生じにくく，従来材種 よりも微細な摩耗粉が形成されているものと考壳られる. このことは前述の UC 6010 の繊維状結晶によるコーティ ング層の強度向上の効果を裏付けるものとなっている。

図13 は，鋳鉄 FC 300 を切削した切れ刃の直角断面を 観察し, 逃げ面摩耗部とすくい面摩耗部のコーティング層 の損傷状態を調べたものである. 従来材種の切れ刃は, コーティング層が工具摩耗によって消失しつつあるが, UC 6010 の切れ刃は，コーティング層の損傷が進行せず, 新切れ刃とほぼ近い状態で残留している。

\section{6. おわりに}

これまでの CVD コーティング技術の改良は，多層化の 歴史であった。著者らは，コーティング層組織の改良を目 指し, Self-Reinforced (自己強化) ${ }^{2}$ ) る呼ばれる方法で, コーティング層の形成中に繊維状の組織をつくることに成 功した。緎維状のコーティング層は強じんで，摩耗進行が 遅く，母材の超硬合金の強度低下も少ない画期的なもので める。この技術を応用したコーテッド超硬合金は，耐摩耗 性，耐欠損性之もに高く，また，多くの被削材で高性能を 発揮する汎用性にも富んでいる.

新コーテッド超硬合金UC 6010 が，今後も切削加工の 高能率化と低コスト化に役立つことを期待したい。

\section{参 考 文 献}

1）鈴木 寿，椙山正孝，梅田高照：WC- $10 \%$ Co 合金の諸性質 と含有炭素量との関係，日本機珹学会誌，28（1964）55.

2）三友竓湾か：ウィスカー, 産業図書, (1993). 